\title{
Social Security of Fishermen Migrant Buton in West Coast, Coast Seram District, Seram West Barat, Maluku Province
}

\author{
Lodewyk Nahuway ${ }^{1}$, Mahmud Tang ${ }^{2}$, Tasrifin Tahara ${ }^{3}$, Ansar Arifin ${ }^{4}$ \\ \{lodewyknahuway@gmail.com¹,mahmud.tang@yahoo.com², tasrifin.tahara@yahoo.co.id ${ }^{3}$, \\ ansararifin@gmail.com $\left.{ }^{4}\right\}$ \\ ${ }^{1234}$ Anthropology Doctoral Program Student, Hasanuddin University Makassar, Sulawesi Selatan, \\ Indonesia
}

\begin{abstract}
This study aims to analyze the forms of social security that occur in the lives of Buton migrant fishermen, both formal and informal. This study uses a qualitative method with a descriptive approach to illustrate various forms of social security of poor fishermen (Masnait) families on the West Coast of Seram Island. Collecting data through in-depth interviews together with informants and observations to see the fishing activities of fishermen and the realities of family life of fishermen. The results showed that the socio-economic and cultural conditions of the families of the fishermen of the community on the west coast of the island of Seram were still in poverty, where the role of his wife and children was still high in supporting the family's economy and a lifestyle that was verified by work undertaken to meet their basic needs. Forms of social security for families of fishermen, both foram and informal, are a guarantee of life for fishing families in the midst of poverty.
\end{abstract}

Keywords-Poverty, social security, bobo fishing nets

\section{Introduction}

Poverty is an issue that has long been a serious concern, especially in developing countries like Indonesia, because poverty is a social problem that is actually faced by society. Therefore, the problem of poverty needs to be a strategic solution for handling poverty in a structured way from the center to the regions with a discourse on the formulation and development of social policies directly to the poor. In the social work literature, social security is one type of social policy to overcome poverty and inequality in society. Each country has different definitions, systems and approaches for dealing with poverty and inequality, and therefore, has different social security systems and strategies.

The broad understanding of social securities can be referred to various individual, group, family, private and government institutions to address the basic living needs of community members such as adequate food, housing, education, health services, clean water, and so on [1].

The process of overcoming socio-economic problems among fishermen requires social security or social security in the community, but social security originating from the Indonesian 
government only applies to ASNs, TNI and Polri. As for fishermen, they have to look for other sources of social security to secure their lives and get out of the poverty problems they face, such as kinship, neighboring, neighborhood and patron-kilen relations providing various kinds of assistance: labor, goods and money [2].

The mechanism of social security system today relies on personal economic activities of individuals and households that must look for economic opportunities and social networks / relationships that are considered beneficial. The economic survival measures of the fishing communities in this study reflect the form of relational attachment in which economic actions are socially embedded and embedded in networks / personal and institutional social relations in social structures. With this situation, economic survival measures are determined by fishermen building economic relationships / networks provided by the market so that the ability to obtain a varied social economic security system among economic actors [3].

The traditional social securities are social security's whose sources are from outside government institutions which have traditionally been given or received from social relations such as relatives, neighbors, people in the same village, friends, patron-clients, and so on. Thus, the term social security can be used to refer to social phenomena at various levels [4].

The forms of social security that are interwoven are formal social security which is a form of social security that is owned by a fishing family sourced from official government institutions in ensuring the life of the community including a fisherman family card, a healthy Indonesian card (KIS), a fishermen's children's education scholarship, to on social security for food security in the form of poor rice (RASKIN); whereas informal social security's include loans from pinggawa for capital needs and fishing gear, lending funds from relatives and family become a social security that is closely related to the socio-economic life of fishing families to assistance from social relations (families) outside the island in the form of basic needs assistance [5]. Butonese migrant fishing communities from Southeast Sulawesi Province who have migrated for a long time in Maluku Province, especially on Seram Island, West Seram Regency. The main work is as a fisherman and consists of groups of fishermen in various types and in relatively relatively large numbers, such as fishing net bobo groups (12-15 people) and katinging fishing groups, and fiber body fishermen (2-4 people). The study in this study is a group of bobo net fishermen who have relatively large members of the fishing laborers (masnait) and these fishing workers are mostly poor fishermen who do not have fishing gear, low capital, low income, and minimal access to education and health. . On the west coast of the island of Seram, around $75 \%$ of poor families are identical to small fishermen who depend on them to work as fishing laborers (masnait) in bobo nets catching units

With the existence of these traditional social security's whose sources are from outside government institutions which have traditionally been given or received from social relations such as relatives, neighbors, people in the same village, friends, patron-clients, etc., it can have a positive impact and help poor fishermen in meeting the needs of his family life.

\section{Method}

This research is a qualitative descriptive study that aims to describe accurately the characteristics of an individual, a particular condition, symptoms, or group, or to determine the frequency or spread of a symptom or the frequency of a certain relationship between a symptom and other symptoms in society [6]. This research is located in Buton villages along the west coast of Seram Island, namely Los Village, Eli Besar Village and Liaela Village, 
Huamual District, West Seram District. The research informants were fishermen catching bobo nets consisting of fishing workers (masnait), fishermen who owned bobo nets, community leaders, and religious leaders. Those chosen as informants are known to have extensive knowledge regarding the values of social securities, and understand the socio-cultural conditions of the Buton people. Data analysis in this study uses qualitative data analysis, which is the process of systematically searching and compiling data obtained from interviews, field notes and other materials, so that it can be easily understood, and the findings can be shared with others [7]. Data processing and data analysis activities are carried out in three stages which include: Data Reduction, namely summarizing, selecting the main points, focusing on important matters, looking for themes and patterns, so that they can provide a clearer picture and make it easier for researchers to do further data collection, and look for it if needed. Presentation of Data is data can be done in the form of a brief description, charts, relationships between categories, flowcharts and the like, and finally Conclusion Withdrawal is done to find out the meaning of all data collected from the beginning to the end of the study.

\section{Result And Discussion}

The activity of catching fish in the sea (piisa) is carried out by means of mangai or the term Moluccas Mangael (fishing around the coast). For example, mangai Dopa (fishing garopa / grouper) in a rather deep sea, mangai sela (fishing tuna and tatihu in the deeper sea). The process of piisa (catching fish) at that time the fishermen used the term kol koli the Moluccan term Kole Kole (a type of canoe that does not use a weigher) and a boat or canoe that uses a weigher (a canoe) carried out by rowing (panggayo) or also with sails

As the development of modernization of fishing, Buton fishermen began fishing using nets around the 1970s, namely drift gill nets, gill circular nets and fixed gill nets, using katintingengined boats or $15 \mathrm{PK}$ jhonson machines, in addition to fishing trolling fishes tuna This development continued among Buton fishermen along the west coast of Seram island until they used the Mini Purse Seine or Bobo nets around 1997 through bobo nets from Hitu on Ambon Island and Luhu State on Seram Huamual Island. . The process of ownership of this bobo nets unit continues from year to year until Buton villages along the west coast of the scary island already have bobo nets catching units in almost every village.

Ships used to operate mini purse-seine fishing gear (bobo nets) by Buton migrant fishermen on the west coast of Seram island use outboard motor boats (soft type). This type of ship is a boat to place fishing gear such as nets, temporary catchment reservoirs and places where fishing activities take place. This ship serves to loop bobo nets (mini purse-seine) in the area of FADs during fishing operations in progress. The operational process of catching a bobo net on the West Coast of Seram Island does not use an auxiliary boat in the form of a jhonson ship (slep type) that functions to pull the net after rounding the catching place, but uses fishing laborers (masnait) to pull it, therefore this bobo nets requires quite a lot of fishing laborers between 1215 people per unit catching bobo nets.

A. Social Security of Fishermen Migrant Buton in West Coast Island of Seram

Fishing families in living their socio-cultural life have a variety of social security systems that apply and are practiced in daily life, and even those social securities that make them able to survive. The poverty of the families of Buton migrant fishermen on the west coast of the island of Seram. Lack of capital, knowledge of fishing gear and uncertain catches make them live in poverty vulnerability, so they need a social security for the family life of fishermen. 
The social security owned by Buton migrant fishing families on the west coast of Seram Island can be divided into two parts, formal and informal social security. Formal security is a social security owned by a family of fishermen sourced from the state and official institutions, while informal security is a social security owned by fishermen sourced from traditional institutions, family, relatives, neighbors, and others.

1. Formal Social Security from the Government Indonesia Healthy Card (KIS)

Health services in West Seram District, especially in Huamual Sub-district have not shown the formation of health services that are sustainable, systematic and structured even though there are health care centers staying in the district center (Negeri Luhu) and health support centers for health services in rural communities in each village. Buton hamlet or village. So that the sick community only consulted with nurses on duty to refer to buying drugs, while for treatment they had to go to the subdistrict center which was quite far from their village. For families of fishermen whose illness is already severe or chronic, the family directly takes them to the General Hospital in Ambon City by sea transportation to the port of Tahuku in the Hila State of Ambon, treatment at the patient's family hospital already has KIS for health services.

The owner or entrepreneur of the owner of the bobo nets has made KIS for all his family members, because of their economic ability. As said by Mr. Sarmon, a fisherman who owns a bobo nets in Los hamlet, where he said: "beta families have used the Indonesia Healthy Card (KIS) for free medical treatment, both at the Puskesmas in the District and referral to the RSU in Ambon City, so very helpful katong a family when sick, beta biking par samua KIS family members for second grade, beta always pay in the District.

Whereas for the families of fishing workers, most of them also have KIS, but they only have KIS when one of their family members is sick, and they process for making the card, and not all family members are included as KIS participants but only husband and wife from the family fisherman. As the results of an interview with one of the family of a fisherman fishing worker Mr. Aher in Liaela dusuin that: This KIS card only my wife and I have, if our children do not have KIS. Because the wife is sick and cared for at the Ambon Hospital, so we are biking KIS for health services at the Hospital. But this has been very helpful for free health services for us as a family.

Thus, poor fishing families are greatly helped by holding free health services through the Indonesia Sehat Card, because they can get good service and are no different from other communities.

2. Child Education Scholarship

The development of formal education for the children of Buton migrant fishermen on the west coast of the spooky island is not yet sufficient, lack of school facilities, supporting facilities and infrastructure for learning, school libraries, and also the problem of fishermen children from fishing laborers' families that is still encountered by children school age who did not attend school because of joining their parents into the sea or gardening, besides that it was also a matter of paying school fees, uniforms and textbooks. So most of these children only go to school until there is an elementary school level and they don't even graduate from junior high school. However, the existence of a scholarship for children's education is very helpful for families of poor fishermen, because the children's facilities and infrastructure for schooling are obtained free of charge from the government, in the form of fees for their school needs. This was stated by one of the bobo nets fishermen workers whose children got a scholarship, Mr. Mustafa Wabula in Liaela Hamlet that: Share private beta by seeing the development of education today with the help of the government to help poor children in the form of scholarships, so that there are no more the reasons for not going to school, everything is 
guaranteed by the government, even if you can get more money, this motivation makes the children of fishermen diligently go to school and study with enthusiasm.

\section{Poor Rice Aid (Raskin)}

The provision of Raskin assistance to these fishing families helps them from the high cost of their basic needs and at the same time serves as evidence of the implementation of maritime development by building quality human resources first. Raskin assistance also makes fishing families able to meet food needs so as to reduce the risk of hunger and malnutrition in fishing families. As one of the fishermen wives of Mrs. Wa Ona in the village of Eli Besar said: Katong is very happy with this assistance, and Katong hopes to continue to be there, who wants to buy us cheap rice like that, but Katong is always grateful to the current government always pay attention to this little community katong.

Thus the poor fishermen community is greatly helped by this cheap rice assistance. Although only each family gets a share of buying $10 \mathrm{~kg}$ at a cost of Rp. 7,000 per $\mathrm{kg}$. but this really helps the poor in food security.

\section{B. Traditional / Informal Social Security In Fishermen Family}

1. Loan Funds from Bobo Fishing Nets Owners

In general, the system of borrowing funds from the owner's fishermen to the fishermen's workers is already common among the bobo net fishermen, the loan money they lend is in addition to business capital, family living needs, children's education costs, health costs and family needs. These loan funds do not require conditions, such as interest, collateral and other administrative requirements. The relationship between the pemilk fisherman and his fishermen's laborers has been established for a long time and is like a family in a work relationship, so that the owner of the fishermen feels that he is also responsible to his fishing laborers to always help them. The process of lending funds is only based on mutual trust. As a fisherman businessman Mr. Husein said in the liaela village: Almost all of the fishing workers here borrow money for business capital from their respective boat bosses. Because there is already mutual trust between the owner's fishermen and the fishing laborers who work on his fishing boat.

The process of lending funds is relatively easy and efficient in time because it does not require a long time so that fishermen can immediately get a loan of funds with general requirements and have been entrenched in the lives of bobo nets fishing workers. Whereas for the process of withdrawing the funds according to the mutual agreement, the loan will be returned at the time of the distribution of the net catch by the owner's fishermen to his fishing laborers. As one of the fisherman laborers, Mr. La Udin in Liaela Hamlet said, there was no interest from the owner of the ship or katong, the boss of the ship, at that time beta was borrowing from the beta capital venture with the wife of a merchant in the village. beta change account in 5 times the payment based on profit sharing ... so at the time of sharing the results the boss has asked the debt to be deducted, and beta agreed to par.

Thus the process of borrowing funds from the owner's fishermen indirectly helps the fishing laborers in meeting their various needs in life.

2. Loan Funds from Family and Relatives

In addition to borrowing funds from the owner's fishermen, loan funds are also often done in a kinship relationship. Poor fishing households to get capital and meet their daily needs is to take advantage of the kin relationship they have. These relatives can take the form of marital fraternal relations and social relations that are built up in employment relationships as fishermen. Utilization of kinship is generally in the form of accounts receivable (loan funds). Poor fishermen often owe money to fulfill their daily needs, especially during the lean season. This is used by poor fishermen as one of the strategies in dealing with poverty. As one of the 
fisherman laborers, Mr. Armon in Los Hamlet, said: in addition to borrowing funds from beta, they have a boss, beta has a family, they often help out when katong needs more, and usually it is beta borrowing from male brothers in Ambon, then sharing the net Bobo just changed beta.

Thus, this poor fishing fisherman can be helped in meeting his daily needs. When they are again in need of funds, they can easily get loans both from the owner's fishermen as well as from family and relatives.

3. Pianapiara, Guaranteed Housing for Education from Family/Relations outside the village or island

The adaptation of Buton people to the population or children of the country in Maluku is very diverse. In principle, they can unite them into one unit, namely the people of Maluku. For the Butonese on the west coast of the island of Seram, it is customary to refer to local residents, the people of the country (mia koliwuno), both for residents of Christian countries and residents of Muslim lands. The process of mixing Buton migrants with the people of the country there, partly formed from the traditional ties that existed between the two social groups, thus making them live in the bond of brothers (brotherhood) among Moluccans.

The relationship between the Butonese and the children of the land was also formed through the stages of the "foster child" or known as pianapiara. The caring parent is called "father piara, if it is male, whereas female is called" mama piara, "in the term" Butonese "for piara parents, is called amapiara and inapiara. This pianapiara stage makes them blend and unite with the local population, so that the communication that is established is not just an interaction can, but the relationship continues to be a family relationship between those who form bonds of foster children and their parents.

This pianapiara stage, usually formed from various introductory relationships or friendship between ordinary people Buton with children of the country there. The interaction took place initially mediocre, then continued to become close acquaintances, so parents who have established friendships, then leave their children while in the world of education in a particular country. From that interaction, it forms a familial bond that is tightened from a pianapiara (child-care relationship).

There are two ways they can get parents, the first is that the parents of the child usually look for the parents' house directly by visiting a house between one particular family of the country and asking (asking) the family's willingness, to look after the child, while he is studying. Usually between parents of children and prospective parents of piara already know each other. Second, there are certain country people (families) who call (look for) young children to settle in their homes. As long as they are children, they are filial to their parents.

\section{Conclusion}

The various forms of social security possessed by Buton migrant fishing families along the west coast of the spooky island that made them able to survive until now are social securities that are formal or informal social securities. Formal social security is a form of social security that is owned by a family of fishermen sourced from official government institutions in ensuring the lives of their communities. First, fisherman family card (KIS) that guarantees fishermen family life (father, mother and child) as a guarantee of family health, secondly fisherman children's education scholarships to guarantee and motivate fishermen children to be able to obtain formal education up to high school level, Third social security for the food security of poor fishermen families, in the form of Poor Rice (Raskin). 
Whereas informal social security mechanisms that have been present are compared to formal ones, loans from fishing owners for capital needs and fishing gear, capital loans for living needs, capital loans for children's education and family health as a social security that can help poor fishermen (fishing laborers) in the sustainability of their lives. Loan funds from the owner's fishermen do not use interest on the loan and there are only agreements and written rules that have been agreed by both parties.

This traditional institution has helped many families of fishermen who lack capital, loans from family and relatives to become a social security that is very closely related to the socioeconomic life of the migrant fishing families of Buton, to assistance from social relations (families) outside the island in the form of assistance basic needs. Even assistance in working relations in the form of fathers among the fishermen, so that children who continue their studies at the sub-district center can live together with the father-father relation from his father. Various kinds of social securities that apply in fishing families show the existence of problem solving mechanisms in the fishing community based on their culture.

\section{References}

[1] Sulastomo, Sistem Jaminan Sosial Nasional. Jakarta: Rajawali Press, 2008.

[2] M. Tang, Aneka Ragam Pengaturan Sekuritas Sosial di Bekas Kerajaan Barru Sulawesi Selatan, Indonesia. Wageningen: Grafisch Service Cantrum Van Gils, 1996.

[3] Mirajiani, "Social Security System Masyarakat Nelayan (Kasus Masyarakat Nelayan Ujung Kulon, Kabupaten Pandeglang, Banten)," Institut Pertanian Bogor, 2015.

[4] M. Tang and et. al, Kajian Sekuritas Sosial bagi Keluarga Nelayan Miskin di Kota Parepare Sulawesi Selatan, Kota Baubau Sulawesi Tanggara, dan Kota Ternate Maluku Utara. Jakarta: Pusat Penerbitan Penelitian Permasalahan Kesejahteraan Sosial Republik Indonesia, 2005.

[5] M. K. Jafar, "Sekuritas Sosial pada Komunitas Nelayan di Pulau Salemo Kabupaten Pangkajene dan Kepulauan Provinsi Sulawesi Selatan," Pascasarjana Universitas Hasanuddin, 2017.

[6] U. Silalahi, Metode Penelitian Sosial. Bandung: Refika Aditama, 2012.

[7] Sugiyono, Metode Penelitian Kuantitatif Kualitatif dan R\&D. Bandung: Alfabeta, 2010. 